\title{
Trial Summary Parameter Value Null Flavor
}

National Cancer Institute

\section{Source}

National Cancer Institute. Trial Summary Parameter Value Null Flavor. NCI Thesaurus.

Code C117459.

A description of the value that describes missing trial summary data values. 